"Retorra RETORIKA

Jurnall Kajian Komunikasi dan Penyiaran Islam

Volume 2, No. 1, 2020

P-ISSN: 2655-5166

E-ISSN: 2715-2103

Homepage : http://journal.iaimsinjai.ac.id/indeks.php/retorika

\title{
PERSEPSI MAHASISWA IAIM SINJAI TERHADAP FENOMENA VIDEO PRANK DI MEDIA SOSIAL
}

\author{
Muhlis $^{1}$, Suriati ${ }^{2}$ \\ ${ }^{1}$ Institut Agama Islam Muhammadiyah Sinjai \\ ${ }^{2}$ Institut Agama Islam Muhammadiyah Sinjai \\ E-mail: Muhlispasca@gmail.com,Tlp:+6285299917154
}

\begin{abstract}
Abstrak
Perkembangan teknologi informasi, berbagai macam aplikasi di internet semakin pesat. Isi yang ada di dalam media internet ini juga semakin kreatif. Selain berdampak positif, sudah tentu juga perkembangan ini juga memiliki dampak negative. Seperti akhir-akhir ini bermunculan video-video prank di media social. Video ini di buat oleh orang-orang yang kreatif. Penelitian ini bertujuan untuk: (1) Mengetahui bagaimana persepsi mahasiswa tentang video prank yanga ada di media sosial (2) Mengetahui dampak video prank tersebut. Metode penelitian yang digunakan metode kualitatif. Pendekatan yang digunakan dalam penelititan ini adalah pendekatan multidisipliner yang meliputi pendekatan sosiologis, pendekatan fenomenologik dan pendekatan psikologis. Dalam metode pengumpulan data, peneliti menggunakan observasi, wawancara dan dokumentasi. Data yang terkumpul, diolah dengan reduksi data, penyajian data dan penarikan kesimpulan. Hasil penelitian menunjukkan bahwa persepsi mahasiswa IAIM Sinjai memberikan tiga kesimpulan yaitu: (1) fenomena video prank ini bisa menjadi hiburan, (2) fenomena video prank ini merupakan sesuatu yang tidak bermanfaat, dan (3) fenomena video prank ini berpotensi untuk merusak generasi bangsa. Sementara dampak yang ditimbulkan dari fenomena video prank ini adalah adanya perubahan pola komsumsi media, ada meniru gaya orang yang membuat prank serta adanya kecendreungan untuk melakukan hal yang sama dengan apa yang mereka lihat di konten video prank tersebut.
\end{abstract}

\section{Kata Kunci: Persepsi, Fenomena Video Prank}

\section{Pendahuluan}

Perkembangan teknologi media informasi berkembang cepat seiring dengan canggihnya industri media informasi dan komunikasi, baik itu cetak maupun elektronik yang menawarkan berita dan sensasi. Dengan derasnya informasi tentu manusia mengalami berbagai macam perubahan baik sosio kultural maupun struktural. Kondisi ini memungkinkan betapa pentingnya informasi dalam 
Retorea RETORIKA

Jurnall Kajian Komunikasi dan Penyiaran Islam

Volume 2, No. 1, 2020

P-ISSN: 2655-5166

E-ISSN: 2715-2103

(9) Homepage : http://journal.iaimsinjai.ac.id/indeks.php/retorika

menanamkan pengetahuan pada peradaban manusia, agar tidak tertinggal dengan kemajuan zaman dan dapat memilah informasi yang baik dan berguna. Untuk mendapatkan informasi dapat melalui bacaan atau mendengar berita, yang salah satunya bisa didapatkan dengan membeli majalah, surat kabar, tabloid dan sebagainya. Bagi sebagian masyarakat dengan membaca lebih memberikan keyakinan kepada dirinya karena ada proses intelektual dan intepretasi yang terjadi ketika membaca berita di media cetak (Ishadi, SK. 1999:159)

Kemajuan teknologi telah menyebabkan perkembangan di berbagai aspek kehidupan. Di zaman yang serba digital sekarang ini, penggunaan internet, smartphone, media sosial sudah sangat umum. Kehidupan yang dinamis menuntut setiap orang untuk dapat mengikuti perubahan agar tidak tertinggal dari yang lainnya. Namun ibarat dua koin yang bersisian kedinamisan kehidupan ini memiliki sisi positif dan negatifnya. Kemajuan teknologi komunikasi membawa kemudahan informasi bagi siapapun. Namun jika tidak digunakan secara tepat maka kemudahan ini bisa menjadi bomerang yang akan menghancurkan bangsa ini khususnya para generasi muda. Internet merupakan salah satu dari kemajuan di bidang informasi, hanya dengan satu kali klik maka informasi akan tersedia secara lengkap. Siapapun bisa mengaksesnya dengan mudah mulai dari anak-anak hingga orang tua. Apalagi dengan munculnya handphone pintar (smartphone), internetan jadi lebih mudah untuk diakses di mana saja dan kapan saja. Manfaatnya tentu tak diragukan lagi, bagi pelajar dan mahasiswa internet dijadikan salah satu sarana belajar dan mencari informasi dan tugas. Namun tak jarang pelajar menggunakan fasilitas internet ini untuk mengakses hal-hal yang sebenarnya dapat merusak mental dan pikiran.

Selain perkembangan teknologi dan informasi, perkembangan isi atau konten dalam sajian berbagai aplikasi dalam internetpun sangat beragam. Setelah sebelumnya viral dengan berbagai challenge yang bertebaran di jagat dunia maya, kini muncul fenomena prank yang sedang ramai dibahas banyak orang. Prank merupakan kata yang berasal dari bahasa Inggris yang memiliki arti gurauan. Sedangkan dalam Kamus Besar Bahasa Indonesia, prank diartikan sebagai senda 
"Retorra RETORIKA

Jurnall Kajian Komunikasi dan Penyiaran Islam

Volume 2, No. 1, 2020

P-ISSN: 2655-5166

E-ISSN: 2715-2103

(8) Homepage : http://journal.iaimsinjai.ac.id/indeks.php/retorika

gurau, kelakar, olok-olok, dan seloroh. Prank di zaman sekarang ini dimaknai sebagai sesuatu guyonan yang bisa dikatakan membohongi seseorang dan bersifat 'mengerjai', diatur seolah-olah serius namun ternyata hanya bohongan dengan tujuan supaya target prank merasa kaget, terkejut, atau bahkan merasa malu. Konten prank sebenarnya tak melulu soal hal-hal yang buruk, namun yang amat disayangkan adalah konten prank yang marak di Indonesia sekarang ini lebih banyak membawa dampak negatif daripada dampak positif (www.ayosemarang.com 2019)

Semua ini mewarnai kompleksitas dunia maya. Sebagai orang yang juga aktif di media social, penulis merasa terpanggil untuk menulis tentang persepsi mahasiswa IAIM Sinjai terhadap video prank yang akhir-akhir ini marak di dunia maya.

\section{Metode}

\subsection{Jenis Penelitian}

Penelitian yang dipakai penulis dalam tulisan ini adalah penelitian kualitatif. Menurut Lexi J. Moleong (2010:6) mengatakan penelitian kualitatif yaitu penelitian yang bermaksud untuk memahami fenomena tentang apa yang dialami oleh subyek penelitian. misalnya prilaku, persepsi, motivasi, tindakan dan lain-lain secara holistik serta dengan cara deskripsi dalam bentuk kata-kata dan bahasa, pada suatu konteks khusus yang alamiah dan dengan memanfaatkan berbagai metode alamiah.

Penelitian ini tergolong jenis penelitian bersifat kualitatif deskriptif, karena penelitian ini memberikan gambaran tentang hasil penelitian dengan mendeskripsikan data-data aktual yang diperoleh di lapangan. Penelitian ini akan mendeskripsikan objek secara alamiah yaitu mengenai persepsi mahasiswa terhadap fenomena video prank yang ada di media sosial.

\subsection{Lokasi Penelitian}

Penelitian ini dilaksanakan di kampus IAIM Sinjai bertempat di Sinjai Sulawesi-Selatan dengan melakukan wawancara langsung terhadap mahasiswa IAIM Sinjai yang aktif di media social. 
Retorrea RETORIKA

Jurnall Kajian Komunikasi dan Penyiaran Islam

Volume 2, No. 1, 2020

P-ISSN: 2655-5166

E-ISSN: 2715-2103

(9) Homepage : http://journal.iaimsinjai.ac.id/indeks.php/retorika

\subsection{Pendekatan Penelitian}

Pendekatan yang digunakan dalam penelititan ini adalah pendekatan multidisipliner yang meliputi pendekatan sosiologis, pendekatan fenomenologik dan pendekatan psikologis. Ketiga pendekatan ini dipergunakan dengan pertimbangan bahwa:

a. Pendekatan fenomenologik digunakan untuk melihat fenomena-fenomena atau fakta-fakta mengenai video prank yang ada di media sosial.

b. Pendekatan sosiologis dipandang sangat relevan dalam kajian penelitian ini, digunakan untuk merujuk kepada konten video prank tersebut dengan kultur dan budaya masyarakat terkhusus di kabupaten sinjai.

c. Pendekatan ilmu psikologis atau ilmu jiwa adalah ilmu yang memperlajari jiwa seseorang melalui gejala perilaku yang dapat diamati. Pendekatan ini dimaksud untuk mengetahui dan mamahami tingkah laku pemeran dalam video prank tersebut.

\subsection{Sumber Data Penelitian}

Sumber data yang diperlukan dalam penelitian ini ada dua, yaitu:

a. Jenis Data

Pada penelitian kualitatif, sampel sumber data bersifat snowball sampling. Penelitian kualitatif sangat erat kaitannya dengan faktor-faktor kontekstual. Maksud sampling dalam hal ini adalah menjaring sebanyak mungkin informasi dari berbagai macam sumber, dengan demikian tujuannya bukanlah memusatkan diri pada adanya perbedaan-perbedaan yang dikembangkan dalam generalisasi. Tujuannya adalah untuk merinci kekhususan yang ada dalam ramuan konteks yang unik.

Maksud kedua dari sampling adalah menggali informasi yang akan menjadi dasar dari rancangan teori yang muncul, jadi pada penelitian kualitatif tidak ada sampel acak, tetapi sampel bertujuan (purposive sample). Teknik snowing sampling dilakukan karena dari jumlah sumber data yang terbatas tersebut belum mampu memberikan data yang konkrit dan lengkap, maka penulis mencari informan yang 
Returea RETORIKA

Jurnall Kajian Komunikasi dan Penyiaran Islam

Volume 2, No. 1, 2020

P-ISSN: 2655-5166

E-ISSN: 2715-2103

(2) Homepage : http://journal.iaimsinjai.ac.id/indeks.php/retorika

dapat memberikan data yang menguatkan hasil penelitian (mengetahui secara jelas data yang diinginkan).

b. Sumber Data

Sumber data yang dimaksud dalam penelitian ini adalah subyek dari mana data diperoleh. Sumber data dalam penelitian ini menggunakan dua jenis sumber data yaitu:

1. Sumber Data Primer, adalah data yang diperoleh secara lansung dari informan yang erat kaitannya dengan masalah yang akan diteliti yaitu persepsi mahasiswa terhadap fenomena video prank di media sosial.

2. Sumber Data Sekunder, merupakan sumber data yang tidak langsung dari informan atau data tambahan yang digunakan bila diperlukan, yang diperoleh melalui penelusuran berupa data dokumen dan laporan serta unsur penunjang lainnya (dokumentasi).

\subsection{Metode Pengumpulan Data}

Kualitas pengumpulan data berkenaan dengan cara-cara yang digunakan untuk mengumpulkan data. Dengan perkataan lain, untuk menjaring data yang dibutuhkan dalam penelitian ini, penulis menggunakan beberapa metode dalam mengumpulkan data, yaitu:

a. Observasi

Observasi digunakan karena beberapa alasan seperti yang dikemukakan oleh Guba dan Linclon dalam Lexy J. Moleong antara lain; teknik pengamatan ini didasarkan atas pengalaman secara lansung, karena pengalaman langsung merupakan alat yang tepat untuk mengetes kebenaran, dan dapat mencatat prilaku dan kejadian yang sebenarnya.

Observasi diambil dari bentuk observasi yang terbagi dua yaitu observasi partisipatif dan observasi non partisipatif. Partisipan dalam arti peneliti langsung melihat dan menganalisi video prank yang ada di media social. Sedangkan non partisipan peneliti lebih berfokus kepada persepsi mahasiswa dalam melihat dan menganalisa fenomena video prank di media sosial. 
"Retorra RETORIKA

Jurnall Kajian Komunikasi dan Penyiaran Islam

Volume 2, No. 1, 2020

P-ISSN: 2655-5166

E-ISSN: 2715-2103

(6) Homepage : http://journal.iaimsinjai.ac.id/indeks.php/retorika

b. Wawancara

Teknik wawancara diawali dengan melakukan persiapan-persiapan pertanyaan yang sesuai dengan rumusan masalah yang diteliti. Kemudian mendesain pertanyaan secara terstruktur, tidak terstruktur, sesuai kondisi psikologis nara sumber (informan) dengan bantuan note book, tape recorder. Mekanisme wawancara dilakukan dengan cara wawancara mendalam (depth interview) yang dilakukan secara individual dan diskusi.

c. Dokumentasi

Dokumen merupakan catatan peristiwa yang sudah berlalu. Dokumen diharapkan lebih kepada video prank yang beredar di media sosial ,beserta dengan komentar dalam video tersebut dari orang yang telah melihat video tersebut.

\subsection{Teknik Pengolahan dan Analisis Data}

Teknik analisis dan interprestasi yang digunakan adalah teori Haberman dan Miles dikutip oleh Bungin. teknik ini dikenal dengan istilah teknik pengolahan data interaktif. Cara kerja dari metode analisis data ini dimulai dari penyajian data, pengorganisasian data, koleksi data, verifikasi data, dan mengambil kesimpulan.

Analisis data adalah proses mencari dan menyusun secara sistematis data yang diperoleh dari hasil wawancara, catatan lapangan, dan dokumentasi, dengan cara mengorganisasikan data ke dalam kategori, menjabarkan ke dalam unit-unit, melakukan sintesa, menyusun ke dalam pola, memilih mana yang penting dan yang akan dipelajari, dan membuat kesimpulan sehingga mudah dipahami oleh diri sendiri maupun orang lain.

Proses dalam analisis data dilakukan melalui tiga tahapan secara berkesinambungan, yaitu mereduksi data, penyajian data dan penarikan kesimpulan.

\section{a. Data Redaktion (Reduksi Data)}

Mereduksi data berarti merangkum, memilih hal-hal pokok, menfokuskan pada hal yang penting. Miles dan Hubermen mengatakan bahwa reduksi data diartikan sebagai proses pemilihan, pemusatan perhatian pada penyederhanaan, pengabstrakan dan transformasi data kasar yang muncul dari catatan-catatan tertulisdi lapangan. 
Retorea RETORIKA

Jurnall Kajian Komunikasi dan Penyiaran Islam

Volume 2, No. 1, 2020

P-ISSN: 2655-5166

E-ISSN: 2715-2103

(6) Homepage : http://journal.iaimsinjai.ac.id/indeks.php/retorika

Mereduksi data bisa berarti merangkum, memilih hal-hal yang pokok, memfokuskan pada hal-hal yang penting, dicari tema dan polanya.

Kegiatan yang dapat dilakukan dalam reduksi data ini antara lain: mengumpulkan data dan informasi dari catatan hasil wawancara dan hasil observasi. Serta mencari hal-hal yang dianggap penting dari setiap aspek temuan penelitian.

\section{b. Data Display (Penyajian Data)}

Penyajian data dalam penilitian kualitatif dapat dilakukan dalam bentuk uraian singkat, bagan, hubungan antar kategori, flowchart dan sejenisnya. Namun yang paling sering digunakan untuk menyajikan data dalam penilitian kualitatif adalah dengan teks yang bersifat naratif. Miles dan Huberman dalam Imam Suprayogo dan Tobroni, mengatakan bahwa yang dimaksud penyajian data adalah menyajikan sekumpulan informasi yang tersusun yang memberikan kemungkinan adanya penarikan kesimpulan dan pengambilan tindakan.

\section{c. Counclusion Drawing (Penarikan Kesimpulan)}

Menurut Miles dan Huberman dalam Harun Rasyid, mengungkapkan bahwa verifikasi data dan penarikan kesimpulan adalah upaya untuk mengartikan data yang ditampilkan dengan melibatkan pemahaman penulis. Kesimpulan yang dikemukakan pada tahap awal, didukung oleh bukti-bukti yang valid dan konsisten saat penulis kembali ke lapangan mengumpulkan data, maka kesimpulan merupakan kesimpulan yang kredibel.

Pada tahap ini dilakukan pengkajian tentang kesimpulan yang telah diambil dengan data pembanding teori tertentu, melakukan proses member check atau melakukan proses pengecekan ulang, mulai dari pelaksanaan pra survei (orientasi), wawancara, observasi dan dokumentasi, kemudian membuat kesimpulan umum untuk dilaporkan sebagai hasil dari penelitian yang telah dilakukan.

Tiga tahap tersebut harus dilakukan secara bertahap oleh penulis. Diawali dari tahap mereduksi data, menyajikan data, kemudian menarik kesimpulan dari seluruhan penelitian. Selanjutnya data yang diperoleh /terkumpul dianalisis dengan cara deskriptif untuk mencari dan menemukan esensi persoalan yang menjadi bahan objek 
"Retorra RETORIKA

Jurnall Kajian Komunikasi dan Penyiaran Islam

Volume 2, No. 1, 2020

P-ISSN: 2655-5166

E-ISSN: 2715-2103

(9) Homepage : http://journal.iaimsinjai.ac.id/indeks.php/retorika

pembahasan. Dari hasil analisa tersebut maka penulis dapat memberikan gambaran subtansi objek kajian mengenai persepsi mahasiswa terhadap video prank di media sosial.

\section{Hasil dan Pembahasan}

\subsection{Persepsi Mahasiswa IAI Muhammadiyah Sinjai Terhadap Video Prank}

Persepsi merupakan sebuah istilah yang sudah sering didengar dalam percakapan sehari-hari. Persepsi berarti pandangan dan pengamatan pribadi seseorang terhadap suatu kejadian atau peristiwa. Jadi yang dimaksud persepsi dalam hal ini adalah tanggapan atau pandangan mahasiswa melihat fenomena video prank. Dari beberapa mahasiswa yang di wawancarai, mereka memberikan informasi yang berbeda beda dengan sudut pandang mereka masing-masing.

Seorang mahasiswa semester yang diwawancarai memberikan keterangan bahwa dia merasa terhibur dengan beberapa video prank yang biasa dilihat di laman facebooknya. Dia memaparkan bahwa : secara pribadi dengan menonton video prank yang ada di facebook ataupun media social yang lain itu memberikan hiburan, karena mampu memberikan tontonan lucu-lucuan yang nyata dan asli dari orang yang di prank tersebut. Seorang mahasiswi yang lain, justru memberikan keterangan berbeda, dia menyatakan bahwa kegiatan dalam video prank yang ada di media social khususnya facebook adalah aksi sama sekali tidak ada manfaatnya. Karena seiriing dengan perkembangan zaman, aksi video prank yang ada hari ini tidak hanya tentang video lucu-lucuan, yang ada adalah banyak konteknya justru merusak generasi bangsa. Di dalam beberapa contoh video yang di maksud adalah konten video prank yang menampilkan adegan yang sepantasnya di pertontonkan seperti ajakan untuk berhubungan suami istri. Selain itu pelaku dan korban seolah-olah melakukan hal tersebut tampa beban social. Padahal aksi video prank tersebut sangat mempengaruhi generasi bangsa, apalagi pengguna media social hari ini di dominasi oleh anak remaja dan dewasa di bawah 30 tahun.

Lain halnya dengan apa yang disampaikan oleh mahasiswa semester 4, dalam menanggapi fenomena video prank yang biasa muncul di facebook, menurutnya 
Returea RETORIKA

Jurnall Kajian Komunikasi dan Penyiaran Islam

Volume 2, No. 1, 2020

P-ISSN: 2655-5166

E-ISSN: 2715-2103

(6) Homepage : http://journal.iaimsinjai.ac.id/indeks.php/retorika

video prank yang ada hari ini mestinya di saring yang bisa di tampilkan di facebook, karena tidak semua video prank itu mengandung bahan lucu-lucuan atau aksi yang kreatif tapi banyak yang keluar dari nilai-nilai social budaya dan agama.

Dan saat ini, prank tengah menjadi fenomena yang mewabah di seluruh dunia termasuk Indonesia. Konten-konten prank seperti itu juga banyak dibuat oleh para YouTuber demi menarik banyaknya likers dan subscriber. Dan faktanya memang konten prank selalu bisa menjadi trending topik di YouTube. Karena banyak peminatnya, akhirnya berbagai konten prank pun membanjiri YouTube. Dengan segala macam adu kreativitas, tapi banyak juga tidak memikirkan resiko dari akibatnya

\subsection{Pandangan Islam Tentang Prank}

Dalam pandangan Islam ada sebuah kisah menarik dari sahabat Rasulullah yang melakukan prank kepada sahabat lain. Dikisahkan Abdurrahman bin Abi Laila, bahwa beberapa sahabat melakukan perjalanan bersama Rasulullah di malam hari. Lalu seorang sahabat tertidur pulas dalam perjalanan tersebut. Beberapa shahabat kemudian hendak bercanda dengan menggendong sahabat yang tertidur ke atas bukit. Begitu tiba di atas bukit, sahabat yang tertidur pun dibangunkan. Kagetlah ia mendapati dirinya berada di atas bukit. Sontak, sahabat lain pun tertawa melihatnya. Mereka hanya melakukannya sebagai candaan dan sekedar main-main. Namun ketika Rasulullah melihatnya, beliau pun memperingatkan;

"Tidak halal bagi seorang muslim menakut-nakuti muslim yang lain." (HR. Abu Dawud dan Ahmad).

Rasulullah mengetahui betul bahwa tidak ada niatan untukl menyakiti dari para sahabat yang menjahili temannya tersebut. Meski hanya bersenda gurau, Rasulullah tetap memperingatkan mereka. Meskipun hanya main-main, gurauan yang menakuti seorang muslim disebut Rasulullah sebagai perkara yang tidak halal atau dilarang. Bersenda Gurau dalam ajaran Islam bukan hal yang dilarang. Apalagi jika gurauan yang dilakukan membuat seseorang kembali segar dan bersemangat. Hanya saja, 
Retorea RETORIKA

Jurnall Kajian Komunikasi dan Penyiaran Islam

Volume 2, No. 1, 2020

P-ISSN: 2655-5166

E-ISSN: 2715-2103

(6) Homepage : http://journal.iaimsinjai.ac.id/indeks.php/retorika

agama ini memberikan batasan-batasan dalam bersenda gurau. Bahkan Rasulullah SAW pun dikatakan dalam sebuah hadis, juga pernah bercanda atau bersenda gurau.

Abu Hurairah Radhiyallahu 'anhu menceritakan, para sahabat bertanya kepada Rasulullah Shallallahu 'alaihi wa sallam : "Wahai, Rasulullah! Apakah engkau juga bersenda gurau bersama kami?" Rasulullah Shallallahu 'alaihi wa sallam menjawab: Betul, hanya saja aku selalu berkata benar. (HR. Abu Hurairah)

\section{Adab Bersenda Gurau}

a. Tak boleh menakuti dan membahayakan orang lain

Islam mengajarkan untuk selalu melakukan perbuatan yang tak merugikan apalagi membahayakan orang lain. Dikatakan dalam sebuah hadits:

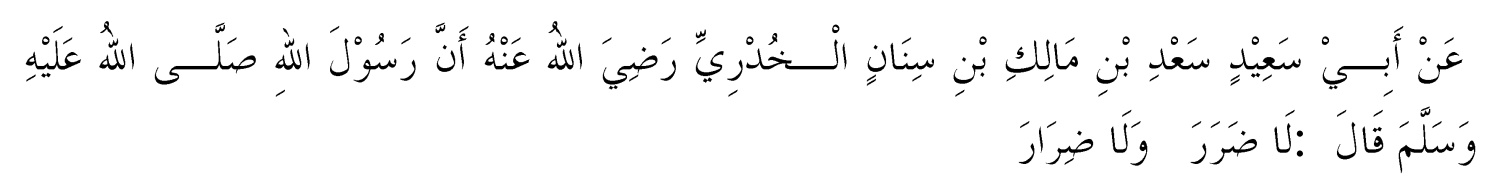

Artinya:

"Dari Abû Sa'îd Sa'd bin Mâlik bin Sinân al-Khudri Radhyallahu anhu, Rasûlullâh Shallallahu 'alaihi wa sallam bersabda, "Tidak boleh ada bahaya dan tidak boleh membahayakan orang lain."

Dalam hadits ini mengandung larangan terhadap segala hal yang bisa mengantarkan kepada bahaya, walaupun bahaya tersebut belum pasti terjadi, baik hal itu dilakukan dengan serius maupun bercanda

b. Tak Boleh menggunakan Simbol Agama

Bersenda Gurau harus dibatasi dengan memperhatikan kontennya. Jangan sampai candaan mengandung pelecehan terhadap syiar, simbol, dan perkara lain terkait agama. Hal tersebut dapat membuat pelakunya terjatuh dalam kemunafikan bahkan kekufuran. hal ini dijelaskan dalam kitab suci Al-Quran:

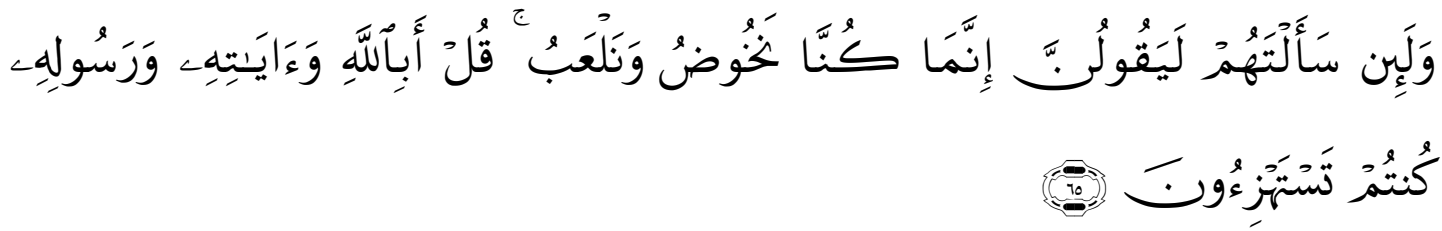

Terjemahnya:

"Dan jika kamu tanyakan kepada mereka (tentang apa yang mereka lakukan

itu), tentu mereka akan menjawab: "Sesungguhnya kami hanya bersenda gurau 
Retortea RETORIKA

Jurnall Kajian Komunikasi dan Penyiaran Islam

Volume 2, No. 1, 2020

P-ISSN: 2655-5166

E-ISSN: 2715-2103

(2) Homepage : http://journal.iaimsinjai.ac.id/indeks.php/retorika

dan bermain-main saja". Katakanlah: "Mengapa kepada Allah,dan ayat-ayatNya serta Rasul-Nya kamu selalu berolok-olok?.” (QS. At-Taubah: 65)

\subsection{Dampak Video Prank Terhadap Mahasiswa}

Perubahan Pola Konsumsi Media Menurut hasil data menunjukkan bahwa kebanyakan remaja lebih banyak mengkonsumsi platform media informasi internet dibandingkan dengan platform media informasi lainnya seperti televisi, surat kabar, radio dan majalah. Karena adanya perubahan pola konsumsi media, Youtube dan facebook menjadi salah satu pilihan utama bagi remaja sebagai tempat untuk mencari informasi dan hiburan. Menonton video-video di facebook telah menjadi rutinitas sehari-hari mereka. Jenis konten video yang paling banyak ditonton oleh remaja yaitu vlog dan prank. Maka tak heran jika banyak sekali bermunculan prank baru karena semakin menjamurnya fenomena vlogging dan prank di Indonesia.

Menurut analisis peneliti, terbukti bahwa terkhusus remaja yang menonton prank telah melakukan identifikasi terhadap seorang yang membuat konten prank yang mereka anggap ideal dan menggunakan hal tersebut dalam perilaku sehari-hari. Adapun sikap dan perilaku yang mereka identifikasi diantaranya, pemilihan barangbarang yang ingin dipakai, perilaku si pembuat prank dalam hal berpakaian (fashion), dalam hal kecantikan (make up), destinasi liburan, cara berbicara, serta cara pandang dari seorang pelaku prank dalam menyikapi suatu permasalahan. Selain itu dampak video prank ini adalah adanya kecendreungan untuk melakukan hal yang sama dengan apa yang mereka lihat di konten video prank tersebut.

\section{Simpulan}

Adapun kesimpulan dari penelitian ini adalah: Pertama, sebagian mahasiswa berpandangan bahwa video prank yang ada di facebook itu merupakan media untuk menghibur karena ada konten lucu-lucuan di dalamnya, sementara yang lainnya berpendapat bahwa konten video prank yang ada itu sama sekali tidak bermanfaat Karena tidak ada edukasi di dalamnya. Bahkan beberapa konten video prank berpotensi merusak generasi bangsa jika konten video tersebut berisi tentang hal yang tidak pantas untuk di pertontonkan. Kedua, dampak video prank adalah adanya 
"Retorra RETORIKA

Jurnal Kajian Komunikasi dan Penyiaran Islam

Volume 2, No. 1, 2020

P-ISSN: 2655-5166

E-ISSN: 2715-2103

(2)

Homepage : http://journal.iaimsinjai.ac.id/indeks.php/retorika

perubahan pola komsumsi media, ada meniru gaya orang yang membuat prank serta adanya kecendreungan untuk melakukan hal yang sama dengan apa yang mereka lihat di konten video prank tersebut.

\section{Daftar Pustaka}

Alo Liliweri. (2002). Makna Budaya dalam Komunikasi antar Budaya. Yogyakarta: PT. LkiS Printing Cemerlang.

Andrik Purwasito. (2003). Komunikasi Multikultural. Muhammadiyah University Press.

Anugrah dan Winny Kresnowati. (2008). Komunikasi Antarbudaya. Bandung: Jala Permata.

Chaney, Lilian,Martin, Jeanette \& Martin. (2004). Intercultural Business Communication. New Jersey: Pearson Education, Inc, Upper Saddle River.

Deddy Mulyana. Komunikasi Efektif: Suatu Pendekatan Lintas Budaya. Bandung. PT. Remaja Rosda karya.

Franz- Josef eilers. (2001). Berkomunikasi dalam Masyarakat, diterjemahkan oleh Frans Obon dan Eduad Jebarus. Bogor: Nusa Indah.

Gudykunst dan Kim. (2002). Intercultural commu nication Theories, dalamWilliam

B.Gudykunst, Bella Mody (ed.), Handbook of International and Intercultural Communication (Second Edition), Thousand Oaks, New Delhi:SAGE Publications Inc.

Imam Suprayogo dan Tobroni. (2001). Metodologi Penelitian Sosial-Agama. Bandung: Remaja Rosdakarya.

Jalaludin Rakhmat. (2003). Psikologi Komunikasi. Bandung: PT. Remaja Rosdakarya.

Jane Pauley. (2001). Quality Communication -Symbols and the Role of Perceptions. New York, Harper Row. 
Returea RETORIKA

Jurmall Kajian Komunikasi dan Penyiaran Islam

Volume 2, No. 1, 2020

P-ISSN: 2655-5166

E-ISSN: 2715-2103

(2)

Homepage : http://journal.iaimsinjai.ac.id/indeks.php/retorika

Koentjaraningrat. (2000). Pengantar Ilmu antropologi. Jakarta : PT. Gramedia

Pustaka Utama.

Kuntowijoyo. (2006). Budaya dan Masyarakat.Yogyakarta:Tiara Wacana.

Larry A.Samovar, Richard E.Porter, dan Edwin R.McDaniel. (2010). Komunikasi Lintas Budaya: Communication Between Cultures. Salemba Humanika: Jakarta.

Lexi J. Moleong. (2009). Metodologi Penelitian Kualitatif Edisi Revisi. Bandung: Remaja Rosdakarya.

Marselina Lagu. (2016). Komunikasi Antarbudaya di Kalangan Mahasiswa Etnik Papua dan Etnik Manado di Universitas Sam Ratulangi Manado (e-journal “Acta Diurna” Volume V. No.3.

Mulyana, Dedi \& Rakhmat, Jalaludin. (2001). Komunikasi Antarbudaya . Bandung: PT. Remaja Rosdakarya.

Onong Uchjana Effendy. (2001). Ilmu Komunikasi Teori dan Praktek. Bandung: PT. Remaja Rosda karya.

Richard Lewis and Dedy Mulyana. (2005). Komunikasi Bisnis Lintas Budaya. Bandung: PT Remaja Rosdakarya Offset.

Sugiono. (2013). Memahami Penelitian Kualitatif. Bandung: Alfabet.

Sugiyono. (2010). Metode Penelitian Kuantitatif Kualitatif dan R N D. Bandung: Alfabeta.

Soehardi. (2001). Kemanusiaan dan kekerasan dalam perspektif Budaya. Dalam : Sumjati \& dkk ( editor ), Manusia dan Dinamika Budaya : Dari Kekerasan Sampai Barata Yuda.

Wilbur Scramm. (1988). Mass Media and National Development. California: Standford University. 